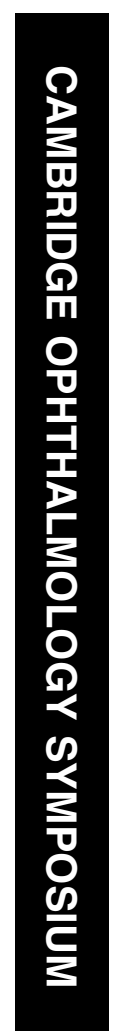

\title{
Molecular genetics of infantile-onset retinal dystrophies
}

\begin{abstract}
Over the last decade there have been major advances in our understanding of the molecular pathology of inherited retinal dystrophies. This paper reviews recent advances in the identification of genetic mutations underlying infantile-onset inherited retinal disorders and considers how this knowledge may lead to novel therapeutic approaches.
\end{abstract}

Eye (2007) 21, 1344-1351; doi:10.1038/sj.eye.6702843

Keywords: retina; inherited; paediatric; gene

\section{Introduction}

The inherited retinal disorders are historically classified according to natural history (stationary or progressive), the mode of inheritance (autosomal dominant (AD), autosomal recessive (AR), $\mathrm{X}$ linked $(\mathrm{XL})$, or mitochondrial), and principal site of retinal dysfunction (pigment epithelium, rod or cone photoreceptor, or inner retina). Such classification involves careful history and examination, and detailed psychophysical and electrophysiological assessment. Such a method of subdividing retinal disease is however unsatisfactory as it may not reflect the molecular pathology of the retinal dysfunction. Advances in molecular genetics of retinal disease have allowed a more precise classification based on the genetic mutations underlying the disorders.

Rapid advances have been made in the field of retinal molecular genetics since the discovery of causative genes began in 1989. The database at Retnet (http://www.retnet.org) lists over 30 identified genes of inherited retinal dysfunction not including the syndromic forms of retinal dystrophies. Some of these genes encode proteins with a well characterised function in the retina, for example phototransduction, but other genes encode either novel proteins or proteins that have hitherto not been suspected to play a role in retinal function. The discovery of these genes has highlighted the role of new biological pathways in retinal structure and function. The identification of the genes underlying inherited retinal disease is an important first step in understanding the mechanism of retinal dysfunction and in developing effective treatment. It also has a more immediate impact on clinical management in improving diagnosis and genetic counselling.

This review aims to discuss the various infantile-onset retinal dystrophies including achromatopsia, blue cone monochromatism (BCM), congenital stationary night blindness (CSNB), and Leber's congenital amaurosis (LCA).

\section{Achromatopsia}

Achromatopsia is a genetically heterogeneous group of AR stationary retinal disorders in which there is an absence of functioning cones in the retina. ${ }^{1}$ Affected individuals have reduced central vision, poor colour vision, photophobia, pendular nystagmus, and usually normal fundi. Achromatopsia may occur in complete (typical) and incomplete (atypical) forms.

Complete achromatopsia (rod monochromatism) has an incidence of approximately 1 in 30000 . The disorder is inherited as an AR trait. The usual presentation is with early infantile-onset of nystagmus, poor visual acuity, and sensitivity to light. Vision is improved in mesopic conditions. Pupil reactions are slow and may show paradoxical responses (pupillary dilation to bright light). A hypermetropic refractive error is common. The nystagmus often improves with age, as can the photophobia. ${ }^{2}$ Fundus examination is generally normal; however, macular atrophy may occasionally be present. Adults with this disorder usually achieve a visual acuity 
of $6 / 60$ to $6 / 36$ and have no true colour vision, although affected individuals may be able to distinguish primary colours using brightness clues. Rod-specific ERGs are normal but there are no detectable conederived responses. ${ }^{3}$ Psychophysical testing reveals that retinal function is determined by rod photoreceptors alone.

Incomplete achromatopsia is best used to describe individuals with AR disease where the phenotype is a variant of complete achromatopsia. Individuals with this variant have better acuity $(6 / 24$ to $6 / 60)$ and retain some residual colour vision. ${ }^{4}$

Three achromatopsia genes have been identified to date, CNGA3, CNGB3, and GNAT2. All encode components of the cone photo-transduction cascade. Mutations in all three genes have been reported in association with complete achromatopsia, ${ }^{5-8}$ whereas only mutations in CNGA3 have been identified in incomplete achromatopsia. ${ }^{9}$

CNGA3 and CNGB3, encode the $\alpha$ - and $\beta$-subunits of the cGMP-gated (CNG) cation channel in cone cells. The cGMP levels are high in cone photoreceptors in the dark, which enables binding to the $\alpha$ - and $\beta$-subunits of CNG channels. This permits an open channel conformation, cation influx, and cone depolarisation. At photopic levels, activated photopigments initiate a cascade producing increased cGMP-phosphodiesterase activity. As a result, the level of cGMP is reduced in the photoreceptor, which leads to closure of CNG cation channels and cone hyperpolarisation. Mutations in CNGA3 and CNGB3 account for the majority of cases of achromatopsia ${ }^{10-12}$ There are over 50 disease-causing mutations in CNGA3 that have been identified in patients with achromatopsia ${ }^{13,14}$ with the majority being missense sequence variants. The CNGA3 gene is highly conserved in evolution and it appears that there is little tolerance for substitutions with respect to the function of the channel polypeptide. Four mutations (Arg227Cys, Arg283Trp, Arg436Trp, and Phe547Leu) account for approximately $40 \%$ of all mutant CNGA3 alleles., ${ }^{15}$ By comparison, approximately only 12 mutations have been identified in CNGB3 ${ }^{16-18}$ with the majority being nonsense variants. The most frequent CNGB3 mutation to date, a 1 base-pair frameshift deletion 1148delC (Thr383fs), accounts for $80 \%$ of CNGB3 mutant disease chromosomes. ${ }^{19,20}$

A third gene, GNAT2, which encodes the $\alpha$-subunit of cone transducin, has also been implicated in achromatopsia. ${ }^{21,22}$ In cone cells, light-activated photopigment interacts with transducin, a three subunit guanine nucleotide binding protein, stimulating the exchange of bound GDP for GTP. The GNAT2 mutations result in premature translation termination and in protein truncation. GNAT2 mutations are thought to be responsible for less than $2 \%$ of patients affected with achromatopsia.

The three genes,CNGA3, CNGB3, and GNAT2 together account for the majority of cases of achromatopsia, but it is likely that there are one or more genes that account for a minority of cases. Uniparental isodisomy of chromosome 14 has been reported in association with an achromatopsia like phenotype ${ }^{23}$ suggesting that there may be an additional achromatopsia gene on chromosome 14 . However, recently a homozygous mutation in CNGB3 has been identified in the original patient with the chromosome 14 rearrangement indicating that it is unlikely that there is a further locus on chromosome $14 .^{24}$

\section{Blue cone monochromatism}

Blue cone (S-cone) monochromatism affects less than one in 100000 individuals; it is characterised by absence of $\mathrm{L}$ and $\mathrm{M}$ cone function. ${ }^{25}$ There is normal rod and short wavelength sensitive cone function . BCM presents in infancy with reduced visual acuity, pendular nystagmus, and photophobia. ${ }^{26}$ The nystagmus often reduces with time. Affected individuals are usually myopic and best-corrected visual acuity is usually in the range of $6 / 24$ to $6 / 60$. Fundus examination is usually normal, but macular atrophy is seen in some older individuals. BCM may be distinguished from achromatopsia by the mode of inheritance, the presence of a myopic rather than hyperopic refractive error and by the results of detailed psychophysical and electrophysiological testing. The photopic ERG is profoundly reduced in both disorders, but the $S$ cone ERG is normal in BCM. ${ }^{27}$ Psychophysical testing in BCM shows evidence of normal S-cone function in comparison to rod monochromats where there is either completely absent cone function or in incomplete forms some residual L- or M-cone function. In clinical practice it is important to use colour vision tests that probe the tritan colour axis as well as the protan and deutan to distinguish RM and BCM; residual tritan discrimination suggests the latter diagnosis. ${ }^{28,29}$

The normal human visual system compares the rate of quantum catches in three classes of cones; the short (S) wavelength sensitive, middle $(M)$ wavelength sensitive, and long (L) wavelength sensitive to light at 430, 535, and $565 \mathrm{~nm}$ respectively. The $\mathrm{L}$ (red) and $\mathrm{M}$ (green) pigment genes are located on the $X$ chromosome and the $S$ cone (blue) pigment is encoded by a gene located on chromosome $7 .^{30}$ The $\mathrm{L}$ and $\mathrm{M}$ opsin genes consist of a tandem array of two or more repeat units of $39 \mathrm{~kb}$ on chromosome $\mathrm{Xq} 28$ that are $98 \%$ identical at the DNA level ${ }^{31,32}$ Mutations in the $\mathrm{L}$ and $\mathrm{M}$ gene array underlie the molecular pathology of BCM. ${ }^{33}$ Such mutations are of two main types. In the first group, the locus control 
region (LCR) (which is common for both normal $\mathrm{L}$ and $\mathrm{M}$ pigment gene arrays), upstream of the L pigment gene is deleted. The deletion abolishes transcription of all genes in the pigment gene array and inactivates $\mathrm{L}$ and $\mathrm{M}$ cones. ${ }^{34}$ In the second group of mutations, the LCR is preserved, but changes within the $\mathrm{L}$ and $\mathrm{M}$ pigment gene array lead to loss of functional pigment production. The commonest genotype is a single inactivated L/M hybrid gene. The first step in this second mechanism is unequal crossing over reducing the number of genes in the array to one, followed in the second step by a mutation that inactivates the remaining gene. A thymine to cystosine transition at nucleotide 648 , resulting in a cysteine to arginine substitution at codon 203 (Cys203Arg), is the most frequent inactivating mutation. ${ }^{35}$ This change disrupts the folding of cone opsin molecules via an absent disulphide bond between two extracellular opsin loops. ${ }^{36}$ A third molecular genetic mechanism has been described in a single family of BCM where exon 4 of an isolated red pigment gene has been deleted. ${ }^{37}$ Approximately $40 \%$ of blue cone monochromat genotypes are due to a one-step mutational pathway that leads to deletion of the LCR, with the remaining cases comprising a heterogeneous group of multistep pathways. ${ }^{38-43}$ A minority of subjects are not found to have disease-causing changes to the opsin array, which raises the possibility that there may be a further genetic mechanism causing this disorder.

\section{Congenital stationary night blindness}

CSNB is characterised by variable non-progressive visual loss, night blindness, and usually normal fundi, although some patients have pale or tilted optic discs. Inheritance may be $A D, A R$ or XL with XL inheritance being most common. In XL and AR patients, the clinical presentation is usually in infancy with nystagmus, moderate to high myopia, strabismus, reduced central vision, and occasionally paradoxical pupil responses. ${ }^{44}$ In contrast $\mathrm{AD}$ disease usually presents with nyctalopia but normal visual acuity; this subtype will not be considered further here. ${ }^{45}$

XL CSNB is subdivided clinically into complete and incomplete forms. Both subdivisions demonstrate a negative ERG, with a selective reduction in the inner nuclear-derived b-wave, so that it is smaller than the a-wave. In complete CSNB, the rod-specific ERG is usually non-recordable. ${ }^{46}$ Cone ERGs reveal subtle abnormalities consistent with $\mathrm{ON}$ bipolar pathway dysfunction. In incomplete CSNB, there is a detectable rod-specific ERG, and cone ERGs are more abnormal than in the complete form. This is due to the involvement of both ON and OFF bipolar pathways. XL and AR disease are very similar clinically and on ERG investigation.
Two genes, CACNA1F and NYX, have been implicated in $\mathrm{XL}$ CSNB. Incomplete CSNB is associated with mutations in $C A C N A 1 F$. This gene encodes the retinaspecific $\alpha_{1 \mathrm{~F}}$-subunit of the voltage-gated L-type calcium channel; it is expressed in the outer and inner nuclear layer and the ganglion cell layer. ${ }^{47,48}$ Most of the mutations reported are inactivating truncation sequence variants. The loss of functional channels impairs the calcium flow into photoreceptors, which is required to sustain neurotransmitter release from presynaptic terminals. The retina remains in a partially lightstimulated state owing to the inability to maintain transmembrane potentials across bipolar cells. Patients are therefore unable to respond to changes in light levels. Most XL CSNB is non-progressive, but in a Japanese family with a retinal disorder caused by a $C A C N A 1 F$ mutation, affected individuals developed progressive loss of visual function and eventually an unrecordable ERG. ${ }^{49}$

Mutations in NYX are associated with complete CSNB. The NYX gene encodes nyctalopin, a proteoglycan with leucine-rich repeats, which are thought to be essential for protein interactions. ${ }^{50}$ Nyctalopin is additionally thought to be involved in the development and structure of the ON pathway.

One form of AR CSNB is associated with mutations in GRM6; this gene encodes the glutamate receptor mGluR6. ${ }^{51}$ Rod and cone receptors mediate synaptic transmission to $\mathrm{ON}$ bipolar cell dendrites via this receptor. More recently, AR CSNB has been associated with homozygous or compound heterozygous mutations in $C A B P 4$, a member of the calcium binding protein (CABP) family. ${ }^{52} \mathrm{CABP} 4$ is located in synaptic terminals and directly associated with the C-terminal domain of the calcium channel Cav1.4. The $\mathrm{Ca}^{2+}$ influx through Cav1.4 triggers the continuous release of glutamate from the photoreceptor synapse in the dark. ${ }^{53}$

\section{Leber's congenital amaurosis}

LCA, first described by Theodor Leber in $1869,{ }^{54}$ is a severe, generalised retinal dystrophy that presents at birth or soon after with nystagmus and severe visual impairment. The disorder accounts for $3-5 \%$ of childhood blindness in the developed world ${ }^{55}$ and has an incidence of $2-3$ per 100000 live births. ${ }^{56}$ It is associated with non-recordable or substantially abnormal rod and cone ERG. ${ }^{57,58}$ The pupils react sluggishly to light and, although the fundus appearance is often normal, abnormal retinal changes including peripheral white dots at the RPE level, macular atrophy, retinal pigmentation, and vascular attenuation may be seen. Other findings include the oculodigital sign, microphthalmos, enophthalmos, strabismus, 
keratoconus, $^{59}$ high refractive error, ${ }^{60}$ cataract, and optic disc swelling.

LCA is usually inherited as an AR disorder, and to date nine genes (GUCY2D, ${ }^{61}$ AIPL1, ${ }^{62}$ RPE65 $5^{63,64}$ RPGRIP1 ${ }^{65,66}$ $C R X^{67,68}$ TULP1 ${ }^{69-71} C R B 1,{ }^{72}$ RDH12, ${ }^{73,74}$ and

CEP $290^{75}$ and a three further loci (LCA3,$^{72}$ LCA $5,^{76}$ and

LCA ${ }^{77}$ ) have been reported to cause LCA. Mutations

in the same genes are also responsible for early childhood-onset severe rod-cone dystrophies, and the term early-onset severe retinal dystrophy (EOSRD) may be a better term to describe a group of disorders including LCA that present in infancy and early childhood. In addition, mutations in two other genes $\left(L R A T^{78}\right.$ and MERKT $\left.T^{79}\right)$ are associated with a similar EOSRD. These genes account for $20-50 \%$ of LCA cases, and the true extent of genetic heterogeneity in this condition remains an area of active research. The relationship between genotype and phenotype has been the subject of several recent reviews and therefore will not be considered further here. ${ }^{80,81}$

\section{Management of infantile-onset retinal dystrophies: current treatment and future therapies}

There is currently no specific treatment for any of these rare infantile-onset retinal dystrophies. However, it is important that the correct diagnosis is made in order to provide accurate prognostic information, and to offer informed genetic counselling, and educational and occupational advice. It is also important to maximise the use of residual vision by the provision of appropriate spectacle correction and low vision aids. Photophobia is often a problematic symptom in cone dysfunction syndromes, and red tinted lenses have been suggested to improve comfort and vision. ${ }^{82}$ Patients may report some improvement with magenta lenses in BCM, which prevent rod desaturation. ${ }^{83}$ In complete achromatopsia, red lenses allow low luminous efficiency wavelengths to be transmitted to the rod photoreceptors. ${ }^{84}$ However, red brown lenses are more effective in incomplete achromatopsia, which have a wider spectral transmission thereby preserving residual colour discrimination. ${ }^{85}$

Given the evidence from some animal models that exposure to light can accelerate photoreceptor cell loss, ${ }^{86}$ it is prudent to avoid exposure to bright lights in children with progressive retinal dystrophy. ${ }^{87}$ A number of possible therapeutic approaches have been suggested for LCA/EOSRD including gene therapy, stem cell treatment, retinal transplantation, and pharmacological approaches such as the use of growth factors or synthetic retinoids. ${ }^{88-93}$ Gene therapy currently appears to be the most promising approach, and the first clinical trials are likely to take place in patients with EOSRD associated with RPE65 mutations. Gene therapy has proved effective in both the LCA Briard dog, ${ }^{91}$ which has a naturally occurring 4 base-pair deletion in the RPE65 gene, and the RPE65 ${ }^{-/-}$mouse. ${ }^{88}$ In the dog model, eyes treated with subretinal injections of adeno-associated virus containing cDNA of canine RPE65 showed significant signs of improvement after treatment in all electrophysiological parameters, pupillometry, and behavioural testing. ${ }^{91}$ Uveitic responses to the novel protein developed in $75 \%$ of trans-gene-treated eyes, but only one eye $(8 \%)$ was refractory to treatment. ${ }^{92}$ These results are grounds for optimism that gene therapy may be equally effective in children with retinal disease due to mutation in RPE65.

Retinal cell transplantation stem cell therapy and the use of neuroprotective agents are other potential therapies. They have the advantage that they are not mutation specific and, in the case of stem cell therapy, could be performed later in the disease process.

Approaches to treatment of retinal dystrophies in animal models have included cell transplantation including ARPE19 cells, ${ }^{94}$ Schwann cells, ${ }^{95}$ brain-derived stem cells, ${ }^{96}$ marrow-derived neural stem cells, ${ }^{97}$ and retinal progenitor cells. ${ }^{98}$ However, preventing tissue rejection and enabling host retinal integration remains a major challenge. Much basic scientific clinical research needs to be carried out before clinical trials of stem cells or transplantation can get underway.

Various neuroprotective substances, including neurotrophic factors, growth factors, cytokines, or combinations of these, have prevented or delayed photoreceptor cell loss in animal models. ${ }^{99-104}$ The most promising of these is CTNF, which has been shown to slowdown photoreceptor degeneration in a large animal model. ${ }^{105}$ CTNF may however induce unwanted changes in retinal structure and function leading to reduced ERG responses ${ }^{106}$ This may limit the therapeutic effect of this approach in the longer term. Phase one clinical trials of CTNF in advanced retinitis pigmentosa in man have been completed. ${ }^{107}$ In this study, human ciliary neurotrophic factor (CNTF) was delivered into the vitreous by cells transfected with the human CNTF gene. The cells were encapsulated in a semipermeable membrane and surgically implanted in the vitreous. There were no serious complications after 6 months of treatment. Phase 2 trials are underway and the results are eagerly awaited.

Much progress has been made in characterising the various forms of infantile-onset retinal dystrophies, and many of the causative genes have been identified; it is likely that the remaining genes will be identified over the next few years. There is increasing optimism that effective therapies will be developed for at least some of these severe disorders. 


\section{Acknowledgements}

This work was funded by the European Union (FP6), EVI-Genoret, Foundation Fighting Blindness USA, and Special Trustees of Moorfields Eye Hospital. This paper is based on a presentation at the Cambridge Ophthalmological Symposium, September 2006.

\section{References}

1 Michaelides M, Hunt DM, Moore AT. The cone dysfunction syndromes. Br J Ophthalmol 2004; 88: 291-297.

2 Simunovic MP, Moore AT. The cone dystrophies. Eye 1998; 12(Part 3b): 553-565.

3 Andreasson S, Tornqvist K. Electroretinograms in patients with achromatopsia. Acta Ophthalmol (Copenh) 1991; 69: 711-716.

4 Pokorny J, Smith VC, Pinckers AJ, Cozijnsen M. Classification of complete and incomplete autosomal recessive achromatopsia. Graefes Arch Clin Exp Ophthalmol 1982; 219: 121-130.

5 Wissinger B, Jagle H, Kohl S, Broghammer M, Baumann B, Hanna DB et al. Human rod monochromacy: linkage analysis and mapping of a cone photoreceptor expressed candidate gene on chromosome 2q11. Genomics 1998; 51: 325-331.

6 Sundin OH, Yang JM, Li Y, Zhu D, Hurd JN, Mitchell TN et al. Genetic basis of total colour blindness among the Pingelapese islanders. Nat Genet 2000; 25: 289-293.

7 Kohl S, Baumann B, Rosenberg T, Kellner U, Lorenz B, Vadala $\mathrm{M}$ et al. Mutations in the cone photoreceptor G-protein alpha-subunit gene GNAT2 in patients with achromatopsia. Am J Hum Genet 2002; 71: 422-425.

8 Aligianis IA, Forshew T, Johnson S, Michaelides M, Johnson CA, Trembath RC et al. Mapping of a novel locus for achromatopsia (ACHM4) to 1p and identification of a germline mutation in the alpha subunit of cone transducin (GNAT2). J Med Genet 2002; 39: 656-660.

9 Wissinger B, Gamer D, Jagle H, Giorda R, Marx T, Mayer S et al. CNGA3 mutations in hereditary cone photoreceptor disorders. Am J Hum Genet 2001; 69: 722-737.

10 Wissinger B, Gamer D, Jagle H, Giorda R, Marx T, Mayer S et al. CNGA3 mutations in hereditary cone photoreceptor disorders. Am J Hum Genet 2001; 69: 722-737.

11 Johnson S, Michaelides M, Aligianis IA, Ainsworth JR, Mollon JD, Maher ER et al. Achromatopsia caused by novel mutations in both CNGA3 and CNGB3. J Med Genet 2004; 41: e20.

12 Kohl S, Baumann B, Broghammer M, Jagle H, Sieving P, Kellner $\mathrm{U}$ et al. Mutations in the CNGB3 gene encoding the beta-subunit of the cone photoreceptor cGMP-gated channel are responsible for achromatopsia (ACHM3) linked to chromosome 8q21. Hum Mol Genet 2000; 9: 2107-2116.

13 Kohl S, Marx T, Giddings I, Jagle H, Jacobson SG, Apfelstedt-Sylla E et al. Total colour blindness is caused by mutations in the gene encoding the alpha-subunit of the cone photoreceptor cGMP-gated cation channel. Nat Genet 1998; 19: 257-259.

14 Wissinger B, Gamer D, Jagle H, Giorda R, Marx T, Mayer S et al. CNGA3 mutations in hereditary cone photoreceptor disorders. Am J Hum Genet 2001; 69: 722-737.
15 Wissinger B, Gamer D, Jagle H, Giorda R, Marx T, Mayer S et al. CNGA3 mutations in hereditary cone photoreceptor disorders. Am J Hum Genet 2001; 69: 722-737.

16 Kohl S, Baumann B, Broghammer M, Jagle H, Sieving P, Kellner $\mathrm{U}$ et al. Mutations in the CNGB3 gene encoding the beta-subunit of the cone photoreceptor cGMP-gated channel are responsible for achromatopsia (ACHM3) linked to chromosome 8q21. Hum Mol Genet 2000; 9: 2107-2116.

17 Johnson S, Michaelides M, Aligianis IA, Ainsworth JR, Mollon JD, Maher ER et al. Achromatopsia caused by novel mutations in both CNGA3 and CNGB3. J Med Genet 2004; 41: e20.

18 Sundin OH, Yang JM, Li Y, Zhu D, Hurd JN, Mitchell TN et al. Genetic basis of total colourblindness among the Pingelapese islanders. Nat Genet 2000; 25: 289-293.

19 Johnson S, Michaelides M, Aligianis IA, Ainsworth JR, Mollon JD, Maher ER et al. Achromatopsia caused by novel mutations in both CNGA3 and CNGB3. J Med Genet 2004; 41: e20.

20 Kohl S, Baumann B, Broghammer M, Jagle H, Sieving P, Kellner $U$ et al. Mutations in the CNGB3 gene encoding the beta-subunit of the cone photoreceptor cGMP-gated channel are responsible for achromatopsia (ACHM3) linked to chromosome 8q21. Hum Mol Genet 2000; 9: 2107-2116.

21 Kohl S, Baumann B, Rosenberg T, Kellner U, Lorenz B, Vadala $\mathrm{M}$ et al. Mutations in the cone photoreceptor G-protein alpha-subunit gene GNAT2 in patients with achromatopsia. Am J Hum Genet 2002; 71: 422-425.

22 Aligianis IA, Forshew T, Johnson S, Michaelides M, Johnson CA, Trembath RC et al. Mapping of a novel locus for achromatopsia (ACHM4) to 1p and identification of a germline mutation in the alpha subunit of cone transducin (GNAT2). J Med Genet 2002; 39: 656-660.

23 Pentao L, Lewis RA, Ledbetter DH, Patel PI, Lupski JR. Maternal uniparental isodisomy of chromosome 14: association with autosomal recessive rod monochromacy. Am J Hum Genet 1992; 50: 690-699.

24 Wiszniewski W, Lewis RA, Lupski JR. Achromatopsia: the CNGB3 p.T383fsX mutation results from a founder effect and is responsible for the visual phenotype in the original report of uniparental disomy 14. Hum Genet 2007 [Jan 31 E-pub ahead of print].

25 Pokorny J, Smith VC, Verriest G. Inherited cone disease. In: Pokorny J, Smith VC, Verriest G, Pinkers AJ (eds) Congenital and Aquired Colour Vision Defects. Grune and Stratton: New York, 2006.

26 Weleber RG, Eisner A. In: Newsome DA (ed). Cone Degeneration and Colour Vision Defects. Retinal Dystrophies and Degenerations. Raven Press: New York, 1988; 233-256.

27 Gouras P, Mackay CJ. Electroretinographic responses of the short-wavelength-sensitive cones. Invest Ophthalmol Vis Sci 1990; 31: 1203-1209.

28 Berson EL, Sandberg MA, Rosner B, Sullivan PL. Color plates to help identify patients with blue cone monochromatism. Am J Ophthalmol 1983; 95: 741-747.

29 Haegerstrom-Portnoy G, Schneck ME, Verdon WA, Hewlett SE. Clinical vision characteristics of the congenital achromatopsias II. Color vision. Optom Vis Sci 1996; 73: 457-465.

30 Nathans J, Piantanida TP, Eddy RL, Shows TB, Hogness DS. Molecular genetics of inherited variation in human color vision. Science 1986; 232: 203-210. 
31 Nathans J, Merbs SL, Sung CH, Weitz CJ, Wang Y. Molecular genetics of human visual pigments. Annu Rev Genet 1992; 26: 403-424.

32 Nathans J, Thomas D, Hogness DS. Molecular genetics of human color vision: the genes encoding blue, green, and red pigments. Science 1986; 232: 193-202.

33 Nathans J, Davenport CM, Maumenee IH, Lewis RA, Hejtmancik JF, Litt M et al. Molecular genetics of human blue cone monochromacy. Science 1989; 245: 831-838.

34 Wang Y, Macke JP, Merbs SL, Zack DJ, Klaunberg B, Bennett $\mathrm{J}$ et al. A locus control region adjacent to the human red and green visual pigment genes. Neuron 1992; 9: 429-440.

35 Kazmi MA, Sakmar TP, Ostrer H. Mutation of a conserved cysteine in the X-linked cone opsins causes color vision deficiencies by disrupting protein folding and stability. Invest Ophthalmol Vis Sci 1997; 38: 1074-1081.

36 Karnik SS, Khorana HG. Assembly of functional rhodopsin requires a disulfide bond between cysteine residues 110 and 187. J Biol Chem 1990; 265: 17520-17524.

37 Ladekjaer-Mikkelsen AS, Rosenberg T, Jorgensen AL. A new mechanism in blue cone monochromatism. Hum Genet 1996; 98: 403-408.

38 Ayyagari R, Kakuk LE, Bingham EL, Szczesny JJ, Kemp J, Toda Y et al. Spectrum of color gene deletions and phenotype in patients with blue cone monochromacy. Hum Genet 2000; 107: 75-82.

39 Ayyagari R, Kakuk LE, Coats CL, Bingham EL, Toda Y, Felius $\mathrm{J}$ et al. Bilateral macular atrophy in blue cone monochromacy (BCM) with loss of the locus control region (LCR) and part of the red pigment gene. Mol Vis 1999; 5: 13

40 Nathans J, Maumenee IH, Zrenner E, Sadowski B, Sharpe LT, Lewis RA et al. Genetic heterogeneity among blue-cone monochromats. Am J Hum Genet 1993; 53: 987-1000.

41 Michaelides M, Johnson S, Simunovic MP, Bradshaw K, Holder G, Mollon JD et al. Blue cone monochromatism: a phenotype and genotype assessment with evidence of progressive loss of cone function in older individuals. Eye 2005; 19: 2-10.

42 Nathans J, Maumenee IH, Zrenner E, Sadowski B, Sharpe LT, Lewis RA et al. Genetic heterogeneity among blue-cone monochromats. Am J Hum Genet 1993; 53: 987-1000.

43 Nathans J, Maumenee IH, Zrenner E, Sadowski B, Sharpe LT, Lewis RA et al. Genetic heterogeneity among blue-cone monochromats. Am J Hum Genet 1993; 53: 987-1000.

44 Price MJ, Judisch GF, Thompson HS. X-linked congenital stationary night blindness with myopia and nystagmus without clinical complaints of nyctalopia. J Pediatr Ophthalmol Strabismus 1988; 25: 33-36.

45 Rosenberg T, Haim M, Piczenik Y, Simonsen SE. Autosomal dominant stationary night-blindness. A large family rediscovered. Acta Ophthalmol (Copenh) 1991; 69: 694-702.

46 Allen LE, Zito I, Bradshaw K, Patel RJ, Bird AC, Fitzke F et al. Genotype-phenotype correlation in British families with $\mathrm{X}$ linked congenital stationary night blindness. $\mathrm{Br} \mathrm{J}$ Ophthalmol 2003; 87: 1413-1420.

47 Bech-Hansen NT, Naylor MJ, Maybaum TA, Pearce WG, Koop B, Fishman GA et al. Loss-of-function mutations in a calcium-channel alpha1-subunit gene in Xp11.23 cause incomplete $\mathrm{X}$-linked congenital stationary night blindness. Nat Genet 1998; 19: 264-267.

48 Strom TM, Nyakatura G, Apfelstedt-Sylla E, Hellebrand H, Lorenz B, Weber BH et al. An L-type calcium-channel gene mutated in incomplete X-linked congenital stationary night blindness. Nat Genet 1998; 19: 260-263.

49 Nakamura M, Ito S, Piao CH, Terasaki H, Miyake Y. Retinal and optic disc atrophy associated with a CACNA1F mutation in a Japanese family. Arch Ophthalmol 2003; 121: 1028-1033.

50 Bech-Hansen NT, Naylor MJ, Maybaum TA, Sparkes RL, Koop B, Birch DG et al. Mutations in NYX, encoding the leucine-rich proteoglycan nyctalopin, cause X-linked complete congenital stationary night blindness. Nat Genet 2000; 26: 319-323.

51 Dryja TP, McGee TL, Berson EL, Fishman GA, Sandberg MA, Alexander KR et al. Night blindness and abnormal cone electroretinogram $\mathrm{ON}$ responses in patients with mutations in the GRM6 gene encoding mGluR6. Proc Natl Acad Sci USA 2005; 102: 4884-4889.

52 Zeitz C, Gruissem BK, Forster U et al. Mutations in CABP4, encoding the Ca-binding protein 4 , cause autosomal recessive night blindness. Am J Hum Genet 2006; 79: 657-667.

53 Rieke F, Schwartz EA. A cGMP-gated current can control exocytosis at cone synapses. Neuron 1994; 13: 863-873.

54 Leber T. Ueber Retinitis pigmentosa und angeborene Amaurose. Albert von Graefes Arch Ophthal 1869; 15: 1-25.

55 Rahi JS, Cable N. Severe visual impairment and blindness in children in the UK. Lancet 2003; 362: 1359-1365.

56 Schuil J, Meire FM, Delleman JW. Mental retardation in amaurosis congenita of Leber. Neuropediatrics 1998; 29: 294-297.

57 Foxman SG, Heckenlively JR, Bateman JB, Wirtschafter JD. Classification of congenital and early onset retinitis pigmentosa. Arch Ophthalmol 1985; 103: 1502-1506.

58 Franceschetti A, Dieterle P. Diagnostic and prognostic importance of the electroretinogram in tapetoretinal degeneration with reduction of the visual field and hemeralopia. Confin Neurol 1954; 14: 184-186.

59 Elder MJ. Leber congenital amaurosis and its association with keratoconus and keratoglobus. J Pediatr Ophthalmol Strabismus 1994; 31: 38-40.

60 Wagner RS, Caputo AR, Nelson LB, Zanoni D. High hyperopia in Leber's congenital amaurosis. Arch Ophthalmol 1985; 103: 1507-1509.

61 Perrault I, Hanein S, Gerber S, Barbet F, Dufier JL, Munnich A et al. Evidence of autosomal dominant Leber congenital amaurosis (LCA) underlain by a CRX heterozygous null allele. J Med Genet 2003; 40: e90.

62 Sohocki MM, Bowne SJ, Sullivan LS, Blackshaw S, Cepko $\mathrm{CL}$, Payne AM et al. Mutations in a new photoreceptorpineal gene on $17 \mathrm{p}$ cause Leber congenital amaurosis. Nat Genet 2000; 24: 79-83.

$63 \mathrm{Gu}$ S, Lennon A, Li Y, Lorenz B, Fossarello M, North M et al. Tubby-like protein-1 mutations in autosomal recessive retinitis pigmentosa. Lancet 1998; 351: 1103-1104.

64 Marlhens F, Bareil C, Griffoin JM, Zrenner E, Amalric P, Eliaou C et al. Mutations in RPE65 cause Leber's congenital amaurosis. Nat Genet 1997; 17: 139-141.

65 Dryja TP, Adams SM, Grimsby JL, McGee TL, Hong DH, Li T et al. Null RPGRIP1 alleles in patients with Leber congenital amaurosis. Am J Hum Genet 2001; 68: 1295-1298.

66 Gerber S, Perrault I, Hanein S, Barbet F, Ducroq D, Ghazi I et al. Complete exon-intron structure of the RPGR-interacting protein (RPGRIP1) gene allows the identification of mutations underlying Leber congenital amaurosis. Eur J Hum Genet 2001; 9: 561-571. 
67 Freund CL, Wang QL, Chen S, Muskat BL, Wiles CD, Sheffield VC et al. De novo mutations in the CRX homeobox gene associated with Leber congenital amaurosis. Nat Genet 1998; 18: 311-312.

68 Jacobson SG, Cideciyan AV, Huang Y, Hanna DB, Freund $\mathrm{CL}$, Affatigato LM et al. Retinal degenerations with truncation mutations in the cone-rod homeobox (CRX) gene. Invest Ophthalmol Vis Sci 1998; 39: 2417-2426.

69 Banerjee P, Kleyn PW, Knowles JA, Lewis CA, Ross BM, Parano E et al. TULP1 mutation in two extended Dominican kindreds with autosomal recessive retinitis pigmentosa. Nat Genet 1998; 18: 177-179.

70 Gu S, Lennon A, Li Y, Lorenz B, Fossarello M, North M et al. Tubby-like protein-1 mutations in autosomal recessive retinitis pigmentosa. Lancet 1998; 351: 1103-1104.

71 Hagstrom SA, Adamian M, Scimeca M, Pawlyk BS, Yue G, $\mathrm{Li}$ T. A role for the Tubby-like protein 1 in rhodopsin transport. Invest Ophthalmol Vis Sci 2001; 42: 1955-1962.

72 Lotery AJ, Jacobson SG, Fishman GA, Weleber RG, Fulton $\mathrm{AB}$, Namperumalsamy $\mathrm{P}$ et al. Mutations in the CRB1 gene cause Leber congenital amaurosis. Arch Ophthalmol 2001; 119: $415-420$

73 Janecke AR, Thompson DA, Utermann G, Becker C, Hubner CA, Schmid E et al. Mutations in RDH12 encoding a photoreceptor cell retinol dehydrogenase cause childhood-onset severe retinal dystrophy. Nat Genet 2004; 36: 850-854.

74 Perrault I, Hanein S, Gerber S, Barbet F, Ducroq D, Dollfus $\mathrm{H}$ et al. Retinal dehydrogenase 12 (RDH12) mutations in leber congenital amaurosis. Am J Hum Genet 2004; 75: 639-646.

75 den Hollander AI, Koenekoop RK, Yzer S, Lopez I, Arends ML, Voesenek KE et al. Mutations in the CEP290 (NPHP6) gene are a frequent cause of Leber congenital amaurosis. Am J Hum Genet 2006; 79: 556-561.

76 Mohamed MD, Topping NC, Jafri H, Raashed Y, McKibbin MA, Inglehearn CF. Progression of phenotype in Leber's congenital amaurosis with a mutation at the LCA5 locus. Br J Ophthalmol 2003; 87: 473-475.

77 Keen TJ, Mohamed MD, McKibbin M, Rashid Y, Jafri H, Maumenee IH et al. Identification of a locus (LCA9) for Leber's congenital amaurosis on chromosome 1p36. Eur J Hum Genet 2003; 11: 420-423.

78 Thompson DA, Li Y, McHenry CL, Carlson TJ, Ding X, Sieving PA et al. Mutations in the gene encoding lecithin retinol acyltransferase are associated with early-onset severe retinal dystrophy. Nat Genet 2001; 28: 123-124.

79 McHenry CL, Liu Y, Feng W, Nair AR, Feathers KL, Ding X et al. MERTK arginine-844-cysteine in a patient with severe rod-cone dystrophy: loss of mutant protein function in transfected cells. Invest Ophthalmol Vis Sci 2004; 45: 1456-1463.

80 Cremers FP, van den Hurk JA, den Hollander AI Molecular genetics of Leber congenital amaurosis. Hum Mol Genet 2002; 11: 1169-1176.

81 Galvin JA, Fishman GA, Stone EM, Koenekoop RK. Clinical phenotypes in carriers of Leber congenital amaurosis mutations. Ophthalmology 2005; 112: 349-356.

82 Park WL, Sunness JS. Red contact lenses for alleviation of photophobia in patients with cone disorders. Am J Ophthalmol 2004; 137: 774-775.

83 Haegerstrom-Portnoy G, Schneck ME, Verdon WA Hewlett SE. Clinical vision characteristics of the congenital achromatopsias II. Color vision. Optom Vis Sci 1996; 73 : 457-465.

84 Haegerstrom-Portnoy G, Schneck ME, Verdon WA, Hewlett SE. Clinical vision characteristics of the congenital achromatopsias II. Color vision. Optom Vis Sci 1996; 73: 457-465.

85 Haegerstrom-Portnoy G, Schneck ME, Verdon WA, Hewlett SE. Clinical vision characteristics of the congenital achromatopsias II. Color vision. Optom Vis Sci 1996; 73 : 457-465.

86 Cideciyan AV, Jacobson SG, Aleman TS, Gu D, PearceKelling SE, Sumaroka A et al. In vivo dynamics of retinal injury and repair in the rhodopsin mutant dog model of human retinitis pigmentosa. Proc Natl Acad Sci USA 2005; 102: 5233-5238.

87 Cideciyan AV, Jacobson SG, Aleman TS, Gu D, PearceKelling SE, Sumaroka A et al. In vivo dynamics of retinal injury and repair in the rhodopsin mutant dog model of human retinitis pigmentosa. Proc Natl Acad Sci USA 2005; 102: 5233-5238.

88 Dejneka NS, Surace EM, Aleman TS, Cideciyan AV, Lyubarsky A, Savchenko A et al. In utero gene therapy rescues vision in a murine model of congenital blindness. Mol Ther 2004; 9: 182-188.

89 Acland GM, Aguirre GD, Bennett J, Aleman TS, Cideciyan $\mathrm{AV}$, Bennicelli J et al. Long-term restoration of rod and cone vision by single dose rAAV-mediated gene transfer to the retina in a canine model of childhood blindness. Mol Ther 2005; 12: 1072-1082.

90 Dejneka NS, Surace EM, Bennett J. Gene therapy for Leber congenital amaurosis. Adv Exp Med Biol 2003; 533: 415-422.

91 Acland GM, Aguirre GD, Ray J, Zhang Q, Aleman TS, Cideciyan AV et al. Gene therapy restores vision in a canine model of childhood blindness. Nat Genet 2001; 28: 92-95.

92 Narfstrom K, Bragadottir R, Redmond TM, Rakoczy PE, van Veen T, Bruun A. Functional and structural evaluation after AAV.RPE65 gene transfer in the canine model of Leber's congenital amaurosis. Adv Exp Med Biol 2003; 533: 423-430.

93 Gouras P, Kong J, Tsang SH. Retinal degeneration and RPE transplantation in Rpe65(-/-) mice. Invest Ophthalmol Vis Sci 2002; 43: 3307-3311.

94 Coffey PJ, Girman S, Wang SM, Hetherington L, Keegan DJ, Adamson $P$ et al. Long-term preservation of cortically dependent visual function in RCS rats by transplantation. Nat Neurosci 2002; 5: 53-56.

95 Lawrence JM, Sauve Y, Keegan DJ, Coffey PJ, Hetherington L, Girman S et al. Schwann cell grafting into the retina of the dystrophic RCS rat limits functional deterioration Royal College of Surgeons. Invest Ophthalmol Vis Sci 2000; 41: $518-528$

96 Wojciechowski AB, Englund U, Lundberg C, Wictorin K, Warfvinge K. Subretinal transplantation of brain-derived precursor cells to young RCS rats promotes photoreceptor cell survival. Exp Eye Res 2002; 75: 23-37.

97 Otani A, Dorrell MI, Kinder K, Moreno SK, Nusinowitz S, Banin $\mathrm{E}$ et al. Rescue of retinal degeneration by intravitreally injected adult bone marrow-derived lineagenegative hematopoietic stem cells. J Clin Invest 2004; 114: 765-774.

98 Coffey PJ, Girman S, Wang SM, Hetherington L, Keegan DJ, Adamson $\mathrm{P}$ et al. Long-term preservation of cortically dependent visual function in RCS rats by transplantation. Nat Neurosci 2002; 5: 53-56. 
99 Caffe AR, Soderpalm AK, Holmqvist I, van Veen T. A combination of CNTF and BDNF rescues rd photoreceptors but changes rod differentiation in the presence of RPE in retinal explants. Invest Ophthalmol Vis Sci 2001; 42: 275-282.

100 Chaum E. Retinal neuroprotection by growth factors: a mechanistic perspective. J Cell Biochem 2003; 88: 57-75.

101 LaVail MM, Yasumura D, Matthes MT, Lau-Villacorta C, Unoki $\mathrm{K}$, Sung $\mathrm{CH}$ et al. Protection of mouse photoreceptors by survival factors in retinal degenerations Invest Ophthalmol Vis Sci 1998; 39: 592-602.

102 Rhee KD, Yang XJ. Expression of cytokine signal transduction components in the postnatal mouse retina. Mol Vis 2003; 9: 715-722.

103 Azadi S, Johnson LE, Paquet-Durand F, Perez MT, Zhang $\mathrm{Y}$, Ekstrom PAR et al. CNTF + BDNF treatment and neuroprotective pathways in the rd1 mouse retina. Brain Res 2007; 1129: 116-129.

104 Faktorovich EG, Steinberg RH, Yasumura D, Matthes MT, LaVail MM. Photoreceptor degeneration in inherited retinal dystrophy delayed by basic fibroblast growth factor. Nature 1990; 347: 83-86.

105 Zeiss CJ, Allore HG, Towle V, Tao W. CNTF induces dosedependent alterations in retinal morphology in normal and rcd-1 canine retina. Exp Eye Res 2006; 82: 395-404.

106 Wen R, Song Y, Kjellstrom S, Tanikawa A, Liu Y, Li Y et al. Regulation of rod phototransduction machinery by ciliary neurotrophic factor. J Neurosci 2006; 26: 13523-13530.

107 Sieving PA, Caruso RC, Tao W, Coleman HR, Thompson DJ, Fullmer KR et al. Ciliary neurotrophic factor (CNTF) for human retinal degeneration: phase I trial of CNTF delivered by encapsulated cell intraocular implants. Proc Natl Acad Sci USA 2006; 103: 3896-3901. 